\title{
Considerations for the use of metal alloys as phase change materials for high temperature applications
}

\author{
A. Inés Fernández ${ }^{1, *}$, Camila Barreneche ${ }^{1}$, Martin Belusko $^{2}$, Mercè Segarra $^{1}$, Frank Bruno $^{2}$, \\ Luisa F. Cabeza ${ }^{3}$ \\ ${ }^{1}$ Materials Science \& Engineering. Departament of Materials Science \& Physical Chemistry, Universitat de \\ Barcelona, C/Martí i Franquès, 1-11, 08028, Spain \\ ${ }^{2}$ Institute for Sustainable Systems and Technologies, University of South Australia, Mawson Lakes Boulevard, \\ Mawson Lakes, SA 5095, Australia \\ ${ }^{3}$ GREA Innovació Concurrent, Edifici CREA, Pere de Cabrera s/n, 25001, University of Lleida, Lleida, Spain \\ *Corresponding author: ana_inesfernandez@ub.edu
}

\begin{abstract}
The use of paraffin, salts and salt hydrates as phase change materials (PCMs) have been researched extensively and used in a number of commercial applications. However, metals and metal alloys, which possess a high storage density on a volume basis as well as a substantially higher thermal conductivity, has received much less attention. This paper discusses the considerations for the use of metal and metal alloys as phase change materials for high temperature thermal storage applications, as well as summarises the literature on the limited research in this area. Although some pure metals and metal alloys present interesting thermal properties to be used as PCMs in thermal storage systems, there is a lack of understanding on the implications of the metallurgical aspects related to the melting and solidification of these materials under thermal cycling at high temperatures. The main issues to be considered include vapour pressure, undercooling, corrosion, segregation, changes in composition and microstructure, changes in thermal properties and undesired reactions. Further research is needed before these materials can be used as PCMs in thermal energy storage systems in industry.
\end{abstract}

Key words: thermal energy storage (TES), phase change materials (PCM), metals, metal alloys, high temperature 


\section{Introduction}

Climate change mitigation is one of the key issues to address for researchers and energy makers $[1,2]$. It is stated that there is an urgent need to develop a new energy supply system as sustainable as possible, that take into account our economic system and our social environment, with the aim of maintaining our resources for future generations. The widespread use of renewable energy has some handicaps, the most important being the intermittence of the resource. The mismatch between supply and demand can be overcome by storing the energy in the form of electricity, heat or mechanically.

Thermal energy storage (TES) is nowadays playing an important role as a complementary technology for renewable energy [3], enabling this energy resource to be utilised throughout the day and night. [4].

TES can use three methods to store heat: sensible heat (SHTES), latent heat (LHTES) and thermochemical storage (TCS) [5]. However, SHTES and LHTES using phase change materials (PCMs) have been more fully-developed and are more widespread in the market [6].

PCMs for high temperature TES systems are actually based on molten salts or eutectic salts compounds $\left[7^{*}\right]$. However, metals can be a very important alternative, which researchers have started to explore [8].

In general, the required properties for a PCM to be used for heat storage can be summarized into three sets of requirements [9]: technical, economic and environmental Physical and technical requirements determine the size and suitability of the thermal storage for a certain application. Low density variation and small volume change, high energy density, small or non-subcooling, non-phase segregation, low vapour temperature, chemical and physical stability, and compatibility with other materials are the most important properties to be considered when choosing a material within this group.

Thermophysical requirements are important for heat storage because the best thermal properties will support the greatest energy efficient system performance. A reproducible phase change at a temperature tailored to the application, with large phase change enthalpy $(\Delta \mathrm{H})$ and specific heat $(\mathrm{Cp})$, as well as high thermal conductivity, and thermal and cycling stability, are the most relevant. 
In addition, economical requirements are extremely significant, as a low price is a key issue to consider for a material for PCM implementation at large scale.

Last but not least, environmental concerns include the ability of the PCM to be recycled or reused, and other environmental factors such as the $\mathrm{CO}_{2}$ footprint, which needs to be minimised, a low embodied energy, which is directly related to energy savings at the end of its life-cycle, or a low toxicity.

Although all of these requirements have their own importance for the development of TES technology using PCM, the improvement of thermophysical properties can provide new challenges as some of them are incompatible thus forcing to find a compromise between the most important ones.

The main objective of this paper is to assess the use of metal and metal alloys for TES, and to highlight which are the challenges of applying these types of materials from the materials science point of view.

\section{State of the art on use of metal and metal alloys as TES materials media.}

Gasanaliev and Gamataeva [10] analyse the thermophysical properties of various thermal cycles and have also specified the perspectives of using metal alloys for heat accumulation. A technical and economic analysis showed that accumulators with high-temperature phase-transition (melting point $>500{ }^{\circ} \mathrm{C}$ ) as heat-carriers, particularly eutectic compositions of salt and metal multi-component systems, are most suitable for non-traditional energy sources [11].

Of all the PCMs used for thermal energy storage, eutectic metal alloys have the greatest thermal conductivities and best stabilities. The analysis of published data on thermodynamic parameters of metal-based multi-component systems $[12,13]$ has made it possible to single out the most promising ones to be used as working materials in heat accumulators (Table 1).

Sharma et al. (2009) [14], Liu et al. (2012) [7] and Rathod and Banerjee (2013) [15] considered some metals and metal eutectics with low melting temperatures as high temperature PCM. The authors claim that these metals have not yet been seriously considered for PCM technology because of weight penalties. However, when volume is taken into account, they become good candidates due to their high heat of fusion per unit volume. Metals and metal alloys also have high thermal conductivities, so fillers normally added in PCM (with added weight penalties) are not required. 
A list of some selected metals and alloys is presented in Table 1. Some of the features of these materials are common to all: (i) low heat of fusion per unit weight, (ii) high heat of fusion per unit volume, (iii) high thermal conductivity, (iv) low specific heat, and (v) relatively low vapour pressure.

Birchenall and Telkes [16], and later Kenisarin (2010) [17], were the first authors who analysed the possibility of storing thermal energy by using the heat of fusion of metals. Starting from that work, Birchenall and Riechman [18] have studied some metal eutectic alloys. Thermal properties of alloys were determined by a differential-scanning calorimeter (DSC) and differential-thermal analysis (DTA). The compositions of the selected alloys were taken from the literature. Initial metals were alloyed in a graphite crucible. The eutectic composition was proved by optical metallography. Experimental facilities were preliminary calibrated by means of pure metals. The measurement error of DTA was $4 \%$ for heat of fusion, and $3 \mathrm{~K}$ for melting temperature. For DSC, the measurement error was $2 \%$ and $1 \mathrm{~K}$, respectively. Five years later, Farkas and Birchenall [19] published new results of the determination of thermophysical properties of some new alloys.

Wang et al. [20] developed and investigated two compositions based on aluminium and silicon. The first alloy, $\mathrm{AlSi}_{12}$, contained $12 \mathrm{wt} \%$ silicon, and the second alloy, $\mathrm{AlSi}_{20}, 20 \mathrm{wt} . \%$ silicon. $\mathrm{AlSi}_{12}$ had a melting temperature of $576{ }^{\circ} \mathrm{C}$ and a heat of fusion of $560 \mathrm{~J} / \mathrm{g}$, and $\mathrm{AlSi}_{20} 585{ }^{\circ} \mathrm{C}$ and $460 \mathrm{~J} / \mathrm{g}$, respectively. Owing to the best properties, alloy $\mathrm{AlSi}_{12}$ was chosen for further studies (its thermophysical properties are given in Table 1). This alloy was used to develop and test a high-temperature isothermal electric heater intended as thermal energy storage at night, when the tariff for the electric power is essentially lower.

Sun et al. [21] investigated one of the ternary eutectic alloys based on aluminium, listed by Farkas and Birchenall 16, $\mathrm{Al}(60$ wt. $\%)-34 \mathrm{Mg}-6 \mathrm{Zn}$. In this study, the compatibility of the specified alloy with materials such as stainless steel SS304L and carbon steel C20 was investigated. The variation in thermal properties of the alloy in regards to the number of melting and solidification thermal cycles was also studied. 
Table 1. Metals and metal alloys considered in the literature as PCMs for high temperature applications.

\begin{tabular}{|c|c|c|c|c|c|c|c|c|c|c|}
\hline \multirow[t]{2}{*}{ Material } & \multirow{2}{*}{$\begin{array}{l}\text { Melting } \\
\text { point } \\
\left({ }^{\circ} \mathrm{C}\right)\end{array}$} & \multicolumn{2}{|c|}{ Latent heat } & \multirow{2}{*}{$\begin{array}{l}\text { Density } \\
(\mathrm{kg} / \mathrm{L})\end{array}$} & \multirow{2}{*}{$\begin{array}{l}\text { Cp (sol) } \\
(\mathrm{kJ} / \mathrm{kg} \cdot \mathrm{K})\end{array}$} & \multirow{2}{*}{$\begin{array}{l}\text { Cp (liq) } \\
(\mathrm{kJ} / \mathrm{kg} \cdot \mathrm{K})\end{array}$} & \multirow{2}{*}{$\begin{array}{l}\text { Thermal } \\
\text { conductivity } \\
(\mathbf{W} / \mathbf{m} \cdot \mathbf{K})\end{array}$} & \multirow{2}{*}{$\begin{array}{l}\text { Volume } \\
\text { expansion } \\
\left(\mathbf{1 0}^{-6} / \mathbf{K}\right)\end{array}$} & \multirow[t]{2}{*}{ Type } & \multirow[t]{2}{*}{ Reference } \\
\hline & & $(\mathrm{kJ} / \mathbf{k g})$ & $(k J / L)$ & & & & & & & \\
\hline $52 \mathrm{Zn}-48 \mathrm{Mg}$ & 340 & 180 & --- & --- & --- & --- & --- & -- & --- & {$[10,19,23]$} \\
\hline $53.7 \mathrm{Zn}-46.3 \mathrm{Mg}$ & 340 & 185 & 851 & 4.600 & --- & $\begin{array}{l}-- \\
\end{array}$ & --- & --- & Eutectic & {$[10,22-24]$} \\
\hline $51 \mathrm{Zn}-49 \mathrm{Mg}$ & 342 & 155 & 442 & 2.850 & 0.73 & --- & 75 & --- & Eutectic $^{(1)}$ & [25] \\
\hline $96 \mathrm{Zn}-4 \mathrm{Al}$ & 381 & 138 & 916 & 6.630 & --- & --- & --- & --- & Eutectic & {$[[10,23-24]$} \\
\hline $55 \mathrm{Mg}-28-17 \mathrm{Zn}$ & 400 & 146 & $\begin{array}{c}-- \\
\end{array}$ & 2.26 & --- & --- & --- & --- & --- & [19] \\
\hline $\mathrm{Zn}(\mathrm{com}$ purity, $\min 99.9 \%)$ & 419 & 112 & --- & 7.140 & 0.39 & 0.48 & --- & $93.5 * * * *$ & ---1 & {$[26]$} \\
\hline 59Al-35Mg-6Zn* & 443 & 310 & --- & 2.38 & 1.63 & 1.46 & --- & --- & --- & {$[10,19,23]$} \\
\hline $60 \mathrm{Al}-34 \mathrm{Mg}-6 \mathrm{Zn}$ & 443 & 312 & $\begin{array}{ll}-- \\
-\end{array}$ & 2.380 & 1.63 & 1.46 & $\begin{array}{c}-- \\
--\end{array}$ & $80.1-93.5$ & --- & [26] \\
\hline 60Al:34Mg:6Zn & 450.3 & 32.1 & --- & --- & --- & --- & --- & --- & --- & {$[23,27]$} \\
\hline $60 \mathrm{Mg}-25 \mathrm{Cu}-15 \mathrm{Zn}$ & 452 & 254 & --- & 2.80 & --- & $\begin{array}{ll}-- \\
\end{array}$ & --- & --- & --- & {$[10,19,23]$} \\
\hline $52 \mathrm{Mg}-25 \mathrm{Cu}-23 \mathrm{Ca}$ & 453 & 184 & --- & 2.00 & --- & --- & --- & --- & --- & {$[10,19,23]$} \\
\hline 86.4Al-9.4Si-4.2Sb & 471 & 471 & --- & --- & --- & --- & --- & --- & Eutectic & {$[23-24]$} \\
\hline $34.65 \mathrm{Mg}-65.35 \mathrm{Al}$ & 497 & 285 & 615 & 2.155 & --- & --- & --- & --- & Eutectic & {$[10,23-24]$} \\
\hline $60.8 \mathrm{Al}-33.2 \mathrm{Cu}-6.0 \mathrm{Mg}$ & 506 & 365 & 111.3 & 3.050 & --- & --- & --- & --- & Eutectic & {$[10,23-24]$} \\
\hline $64.1 \mathrm{Al}-5.2 \mathrm{Si}-28 \mathrm{Cu}-2.2 \mathrm{Mg}$ & 507 & 374 & 164.4 & 4.400 & --- & --- & --- & --- & Eutectic & {$[10,23-24]$} \\
\hline 54Al-22Cu-18Mg-6Zn & 520 & 305 & --- & 3.14 & 1.51 & 1.13 & --- & --- & --- & {$[10,19,23]$} \\
\hline 68.5Al-26.5Cu-5.0Si & 525 & 364 & 106.9 & 2.938 & --- & $\begin{array}{ll}-- \\
\end{array}$ & --- & --- & Eutectic & {$[10,23-24]$} \\
\hline $64.3 \mathrm{Al}-34.0 \mathrm{Cu}-1.7 \mathrm{Sb}$ & 545 & 331 & 132.4 & 4.000 & --- & --- & --- & --- & Eutectic & {$[10,23-24]$} \\
\hline $66.92 \mathrm{Al}-33.08 \mathrm{Cu}$ & 548 & 372 & 133.9 & 3.600 & --- & --- & --- & --- & Eutectic & {$[10,23-24]$} \\
\hline 83.14Al-11.7Si-5.16Mg & 555 & 485 & 121.3 & 2.500 & --- & --- & --- & --- & Eutectic & {$[10,23-24]$} \\
\hline $87.76 \mathrm{Al}-12.24 \mathrm{Si}$ & 557 & 498 & 126.5 & 2.540 & --- & --- & --- & --- & Eutectic & {$[10,23-24]$} \\
\hline $49.1 \mathrm{Cu}-46.3 \mathrm{Al}-4.6 \mathrm{Si}$ & 571 & 406 & 226.0 & 5.560 & --- & --- & --- & --- & Eutectic & {$[10,23-24]$} \\
\hline 65Al-30Cu-5Si & 571 & 422 & --- & 2.73 & 1.30 & 1.20 & --- & --- & --- & {$[10,19,23]$} \\
\hline 86.4Al-9.4Si-4.2Sb & 575 & 471 & 127.2 & 2.70 & --- & --- & --- & --- & Eutectic & {$[10,23-24]$} \\
\hline 88Al-12Si & 576 & 560 & $\begin{array}{ll}-- \\
\end{array}$ & 2.70 & 1.038 & 1.741 & 160 & $\begin{array}{ll}-- \\
\end{array}$ & Alloy & {$[20]$} \\
\hline $88 \mathrm{Al}-12 \mathrm{Si}$ & 576 & 560 & --- & 2.700 & 1.04 & 1.74 & $\begin{array}{ll}-- \\
\end{array}$ & $63.9 * *$ & Metal & [26] \\
\hline 86Si:12Al & 576 & 560 & --- & 2.700 & & & --- & --- & Metal & {$[23,21]$} \\
\hline $88 \mathrm{Al}-12 \mathrm{Si}$ & 576 & 560 & --- & --- & --- & --- & --- & --- & Alloy & {$[28-30]$} \\
\hline $88 \mathrm{Al}-12 \mathrm{Si}$ & 577 & 462 & --- & --- & 0.939 & --- & 181 & & Alloy & {$[28,31-32]$} \\
\hline $80 \mathrm{Si}: 20 \mathrm{Al}$ & 585 & 460 & --- & --- & --- & --- & --- & --- & Alloy & {$[21,23]$} \\
\hline
\end{tabular}


Table 1. (following part)

\begin{tabular}{|c|c|c|c|c|c|c|c|c|c|c|}
\hline $\mathrm{Zn}_{2} \mathrm{Mg}$ & 588 & 230 & --- & --- & --- & --- & & --- & --- & [19] \\
\hline $\mathrm{Mg}$ (commercial purity) & 648 & 365 & --- & 1.740 & 1.27 & 1.37 & --- & $87 * *$ & Metal & [26] \\
\hline Al (commercial purity, 1-0 wrought) & 661 & 388 & --- & 2.700 & 0.90 & 0.90 & --- & $80.1 * * *$ & Metal & [26] \\
\hline $49 \mathrm{Zn}-45 \mathrm{Cu}-6 \mathrm{Mg}$ & 703 & 176 & --- & 8.67 & 0.42 & --- & --- & --- & Alloy & {$[10,19,23]$} \\
\hline $91 \mathrm{Cu}-9 \mathrm{P}$ & 715 & 134 & --- & 5.60 & --- & --- & --- & --- & Alloy & {$[10,19,23]$} \\
\hline 69Cu-17Zn-14P & 720 & 368 & --- & 7.00 & --- & --- & --- & --- & Alloy & {$[9,10,19,23.27,29], 29$} \\
\hline 74Cu-19Zn-7Si & 765 & 125 & --- & 7.17 & --- & --- & --- & --- & Alloy & {$[10,19,23]$} \\
\hline $56 \mathrm{Cu}-27 \mathrm{Si}-17 \mathrm{Mg}$ & 770 & 420 & --- & 4.15 & 0.75 & --- & --- & --- & Alloy & {$[10,19,23]$} \\
\hline $84 \mathrm{Mg}-16 \mathrm{Ca}$ & 790 & 272 & --- & 1.38 & $\begin{array}{ll}--- \\
\end{array}$ & --- & --- & --- & Alloy & {$[10,19,23]$} \\
\hline 47Mg-38Si-15Zn & 800 & 314 & --- & --- & --- & $\begin{array}{ll}-- \\
\end{array}$ & --- & $\begin{array}{ll}-- \\
\end{array}$ & Alloy & {$[10,19,23]$} \\
\hline $80 \mathrm{Cu}-20 \mathrm{Si}$ & 803 & 197 & --- & 6.60 & 0.50 & --- & --- & --- & Alloy & {$[10,19,23]$} \\
\hline $83 \mathrm{Cu}-10 \mathrm{P}-7 \mathrm{Si}$ & 840 & 92 & --- & 6.88 & --- & --- & --- & --- & Alloy & {$[10,19,23]$} \\
\hline $\mathrm{Mg}_{2} \mathrm{Cu}$ & 841 & 243 & --- & $\begin{array}{ll}-- \\
\end{array}$ & $\begin{array}{ll}-- \\
\end{array}$ & $\begin{array}{ll}--- \\
\end{array}$ & --- & $\begin{array}{ll}-- \\
\end{array}$ & Alloy & [19] \\
\hline $49 \mathrm{Si}-30 \mathrm{Mg}-21 \mathrm{Ca}$ & 865 & 305 & --- & 2.25 & --- & --- & --- & --- & Alloy & {$[10,19,23]$} \\
\hline $56 \mathrm{Si}-44 \mathrm{Mg}$ & 946 & 757 & --- & 1.90 & 0.79 & --- & --- & --- & Alloy & {$[10,19,23]$} \\
\hline $\mathrm{Cu}$ & 1077 & 71 & --- & --- & $\begin{array}{ll}--- \\
\end{array}$ & $\begin{array}{ll}--- \\
\end{array}$ & --- & $\begin{array}{ll}--- \\
\end{array}$ & Metal & [33-34] \\
\hline
\end{tabular}


The metal samples investigated were immersed in a capsule, which were placed in a stainless

Table 2. Change of melting temperature of the Al(59)-35Mg-6Zn alloy 25

\begin{tabular}{|l|c|c|c|c|}
\hline & 0 cycles & 50 cycles & 500 cycles & 1000 cycles \\
\hline $\begin{array}{l}\text { Melting } \\
\text { temperature }\left({ }^{\circ} \mathrm{C}\right)\end{array}$ & $450.3-455.7$ & $450.3-454.3$ & $448.6-452.8$ & $447.3-450.4$ \\
\hline
\end{tabular}

Khare et al. (2012) [26] used a materials selection procedure and found that metals such as Al, $\mathrm{Mg}$, Si and $\mathrm{Zn}$, and their eutectics $88 \mathrm{Al}-12 \mathrm{Si}$ and $60 \mathrm{Al}-34 \mathrm{Mg}-6 \mathrm{Zn}$ were highly suitable as a PCM for the duty considered in their research (steam generation from 400 to $750{ }^{\circ} \mathrm{C}$ ). Their properties, heat of fusion, thermal conductivity, etc. have advantages in the application considered over traditional molten salts, with $88 \mathrm{Al}-12 \mathrm{Si}$ showing the best environmental performance as well. The heat transfer effectiveness of this alloy was also evaluated by the eNTU method [26] and favourably compared to the HiTech nitrate based molten salt using heat exchanger geometry. The authors used materials selection software based on a multi-objective optimisation methodology, by considering environmental conditions and eco-properties.

Sun et al. $[4,21]$ determined the thermal stability and corrosion characteristics of Al-34\% Mg$6 \% \mathrm{Zn}$ alloy when used as latent heat energy storage material. The melting temperature and latent heat of fusion for this alloy were $454^{\circ} \mathrm{C}$ and $314.4 \mathrm{~J} / \mathrm{g}$, respectively. Thermal stability was checked for 1000 thermal cycles, but the microstructure potential changes were not taken into account. The container materials considered in the corrosion tests carried out in this study were stainless steel (SS304L) and carbon steel (SteelC20). The DSC results indicated that the change of the melting temperature of the alloy was in the range of $3.06-5.3{ }^{\circ} \mathrm{C}$, and that the latent heat of fusion decreased $10.98 \%$ after 1000 thermal cycles. The results showed that the $\mathrm{Al}-34 \% \mathrm{Mg}$ $6 \% \mathrm{Zn}$ alloy under study had reasonably good thermal reliability as a latent heat energy storage material. Table 1 shows the details of the above-mentioned material.

Cárdenas and León (2013) [23] listed the metals and metal alloys with melting temperatures above $300{ }^{\circ} \mathrm{C}$ proposed and studied by various other researchers as possible high temperature 
1 PCM. As previous authors, they claimed that the use of metal alloys as a PCM had been

2 underestimated by researchers even though they have desirable properties such as high thermal

3 conductivity, high corrosion resistance, and small volume change associated with phase change,

4 and no subcooling. Therefore, for certain applications, metal and metal alloys present higher

5 thermophysical properties and they are able to compete with salts, especially when weight is not

6 a decisive factor. Nieto-Maestre et al [35] focused in the particular temperature range between

$7285^{\circ} \mathrm{C}$ and $330^{\circ} \mathrm{C}$ for direct steam generation DSG, using Thermo-Calc software and SSOL4

8 thermodynamic database for different ternary and quaternary metallic systems combining $\mathrm{Mg}$

9 and $\mathrm{Zn}$, with $\mathrm{Cu}$ and $\mathrm{Ni}$ for the ternary systems and $\mathrm{Mg}-\mathrm{Zn}-\mathrm{Al}-\mathrm{Cu}, \mathrm{Mg}-\mathrm{Zn}-\mathrm{Al}-\mathrm{Sn}, \mathrm{Mg}-\mathrm{Zn}-\mathrm{Cu}-$

$10 \mathrm{Sn}$, for the quaternaries, though the most promising eutectics in terms of $\mathrm{T}_{\mathrm{m}}$ and $\Delta \mathrm{H}_{\mathrm{f}}$ were the ternary combinations.

In addition, some authors propose that the use of eutectic metals as TES medium is feasible for industrial processes [18], that metals and metal alloys can be used as waste heat storage media [36], and that $\mathrm{AlSi}_{12}$ [20] and $\mathrm{AlMg}_{34} \mathrm{An}_{6}$ [21] are also suitable to be used as PCM.

Pure metals as PCM

PCM store energy following the Eq. 1 where $Q_{\text {latent }}$ is the heat accumulated during the phase change as latent heat, $C p$ is the specific heat at solid $\left(C_{p, s}\right)$ or liquid $\left(C_{p, l}\right)$ stage and $\Delta H_{p c}$ is the phase change enthalpy.

$$
Q_{\text {latent }}=\int_{T_{1}}^{T_{p c}} C_{p, s} \cdot d T+\Delta H_{p c}+\int_{T_{p c}}^{T_{2}} C_{p, l} \cdot d T
$$

Zhang et al. (2014) [33] used copper as PCM and encapsulated it with refractory metallic shells, to be used up to $1000^{\circ} \mathrm{C}$. Copper spheres with a diameter of few millimetres were encapsulated with a thick chromium-nickel bilayer by a novel chromium periodic-barrel electroplating method and a nickel barrel-plating method. The latent heat density of as-prepared capsules was up to $75 \%$ of the theoretical value (about $71 \mathrm{~J} / \mathrm{g}$ ) at the melting temperature of $1077^{\circ} \mathrm{C}$, and the thermal resistance of chromium-nickel layer was $8.27 \cdot 10-6 \mathrm{~m}^{2} \cdot \mathrm{K} / \mathrm{W}$. Principally, copper capsules could endure 1000 charge-discharge thermal cycles from $1050{ }^{\circ} \mathrm{C}$ to $1150{ }^{\circ} \mathrm{C}$ without any leakage. The structure investigations (see Figure 1) revealed the excellent oxidation resistance of the capsules and good stability between copper and the chromium-nickel layer, even after long-term charge-discharge cycles. The results demonstrated that as-prepared copper capsules were applicable as high temperature PCM, which could facilitate high temperature thermal energy storage systems. 

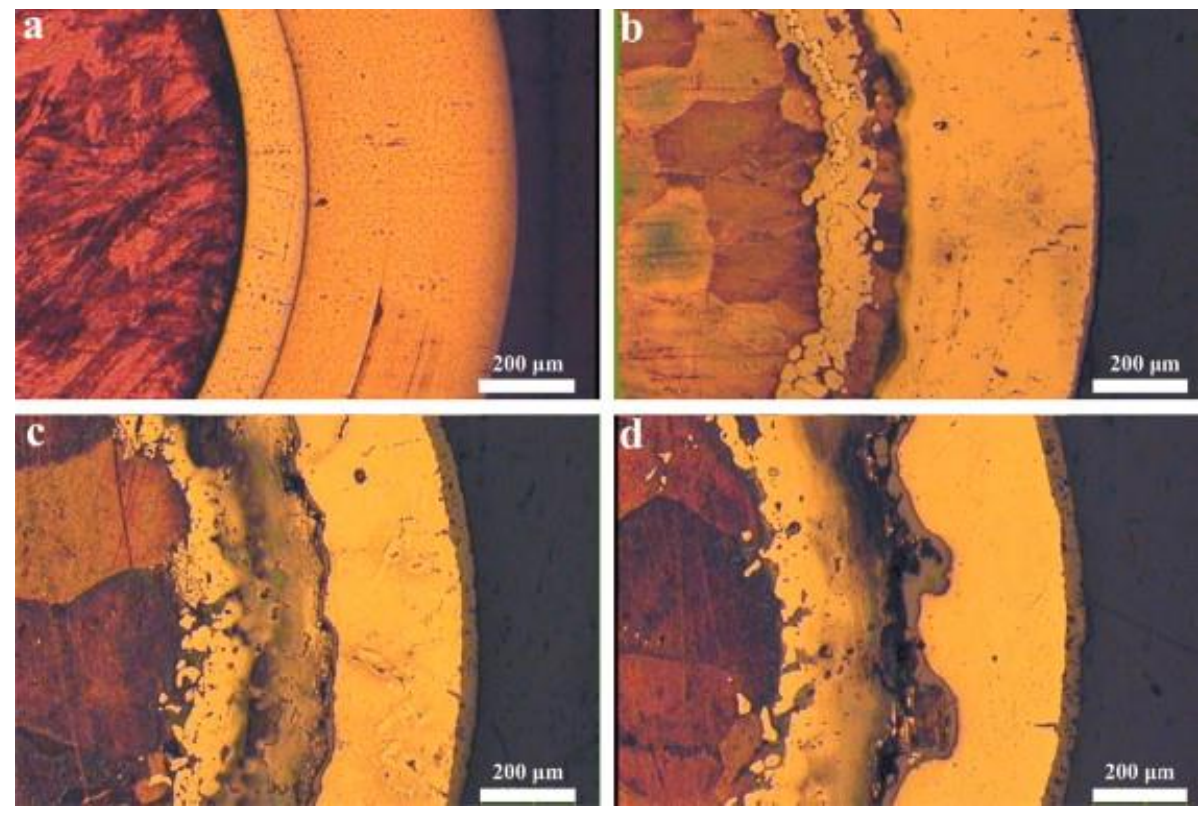

Figure 1. Morphology change of capsules with different charge-discharge cycles from $1050{ }^{\circ} \mathrm{C}$ to $1150{ }^{\circ} \mathrm{C}[33]$

Ma et al. (2014) 31 used copper as PCM and encapsulated it with iron at micro level. They discussed the formation of $\mathrm{Fe}-\mathrm{Cu}$ alloys. Results showed that the morphology evolution of $\mathrm{Fe}-$ $\mathrm{Cu}$ alloys could be attributed to the combined effects of the liquid phase fraction of the two immiscible liquids, Stokes and Marangoni velocities of droplets, and the rotation direction of the alloy samples during solidification. This type of encapsulated metallic-PCM (EM-PCM) is nearly spherical with a diameter of about $2 \mathrm{~mm}$ and coated by an iron oxide layer which can improve the wear resistance of EM-PCMs.

\section{Metal alloys as PCM}

Kotzé et al. (2013) [28] selected the eutectic alloy of aluminium and silicon, $\mathrm{AlSi}_{12}$, as one of the best candidates as metallic PCM based on a review of the literature. This alloy has a heat of fusion of $560 \mathrm{~J} / \mathrm{g}$ and a melting point of $576{ }^{\circ} \mathrm{C}$ [20]. Li et al. [29] conducted a study on the suitability of aluminium-silicon alloys when used as PCM. They found that aluminium-silicon alloys are relatively stable through multiple heating and cooling cycles. In addition, Kotze et al. (2014) [32] used the same eutectic aluminium silicon alloy ( $\left.\mathrm{AlSi}_{12}\right)$ as PCM in a prototype thermal energy storage test rig because of its moderate melting temperature, high thermal conductivity, and high heat of fusion. The concept is shown in Figure 2. Note that the PCM is located inside tubes and the steam cross these tubes by water pipes (with dots) in combination with $\mathrm{NaK}$ pipes (black dots). 


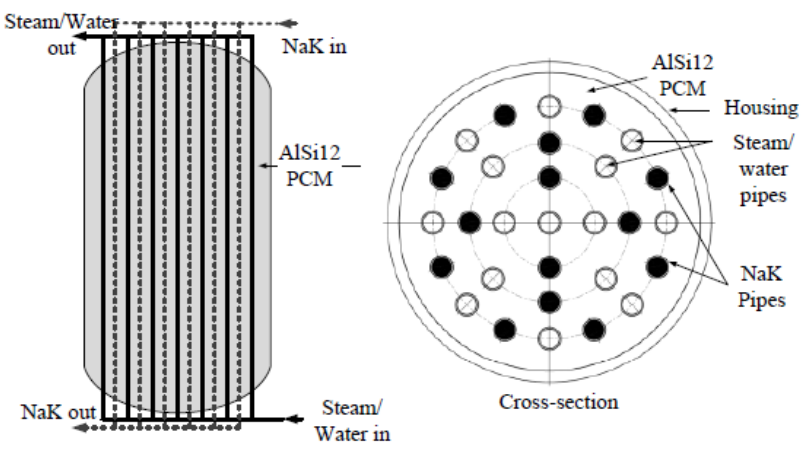

Figure 2. Kotze et al. concept composed by AlSi ${ }_{12}$ [32].

Blanco-Rodríguez et al. (2014) [25] presented a eutectic metal alloy, Mg-51\%Zn, to be used as PCM for TES in CSP. They characterized extensively this eutectic metal alloy between room temperature and its melting temperature according to the phase diagram. A first conclusion drawn by these authors is that the phases present at room temperature depend on the synthesis settings and subsequent heating and cooling cycles. On the one hand, the main advantages of this eutectic metal alloy are its better thermal diffusivity, heat capacity and energy density compared to molten salts. On the other hand, the main drawback is its price.

Moreover, Risueño et al. [37] have developed some light-weight alloys based on Mg-Zn-Al to be used in latent heat storage applications. They suggest that among the studied compositions, the $\mathrm{Mg}_{70} \mathrm{Zn}_{24.9} \mathrm{Al}_{5.1}$ eutectic alloy could be the best candidate.

Andraka et al. [35], have synthesized and characterized metallic based PCM composed by CaSi $\left(\operatorname{Tm} 782^{\circ} \mathrm{C}\right.$ ) and CuMgSi $\left(\operatorname{Tm} 742^{\circ} \mathrm{C}\right)$, as proposed storage system for matching the isothermal input feature of Stirling engines. Their study includes evaluation of compatibility with container materials, and center the compatibility issues on silicon.

These very recent publications put on relevance the potential of these kind of materials as well as these thermal conductivity properties, phase change issues, energy density, etc.

\section{Melting/solidification of pure metals and metal alloys}

Usually, a pure metal solidifies by crystallization through nucleation and crystal growth, leading to a polycrystalline structure. It occurs in some of the three common crystal structures: bodycentred cubic or BCC (Na, K, Mo, Fe, Ti), face-centred cubic or FCC (Al, Co, Cu, Fe), and hexagonal close-packed or HCP (Cd, Co, Mg, Ti, Zn), showing some of them polymorphism.

There are two types of nucleation: homogeneous and heterogeneous. In the first one, new phase nuclei appear in all the bulk material, while in the second, the first nuclei are formed just next to 
any heterogeneity present in the material, such as solid impurities or grain boundaries, or even at the container walls.

Assuming homogeneous nucleation, and knowing the interfacial energy, $\gamma$, between a crystal and its melt, the degree of subcooling is estimated as $\theta \cong 0.2 \mathrm{~T}_{m}$ [38]. After nucleation, crystal growth occurs at a rate that increases as the square of the degree of subcooling, giving very fast rates in pure metals, e.g. $40 \mathrm{~m} / \mathrm{s}$ in Ni undercooled $175^{\circ} \mathrm{C}$ [38]. In foundries, the temperature of interface is near the ideal melting point and thus the rate of growth becomes the rate of removal of latent heat from the interface.

As stated by Professor Cottrell [38], the presence of impurities may lead to changes of viscosity entailing to pre-crystallization before reaching the thermodynamic transition temperature, and thus affecting the freezing behaviour. Otherwise, a dendritic growth occurs in cast impure metals because the soluble impurities and alloying elements promote dendritic crystallisation, thus revealing microstructures with inhomogeneous composition, having, as a consequence, constitutional undercooling. Casted metals may show different structures because of the selective growth forming grains with different sizes or shapes: columnar or equi-axed. Moreover, by modifying the temperature gradient starting from a superheated liquid, or increasing the cooling rate, may lead to extremely different structures with a coarse columnar structure for the first case, and a fine grained equi-axed crystals structure for the second one.

Moreover, other factors influencing the grain structure and determining the quality of a cast metal are shrinkage, segregation and gas evolution. Shrinkage originates many practical difficulties in the casting of metals as it produces mechanical stresses and cracks, e.g. aluminium shrinks about $12 \%$ in volume from the liquid to the solid state at room temperature. It is important at microscopic scale as it can lead to a casting full of fine-scale porosity. Segregation refers to all non-uniformities of composition in an ingot or casting, and can be macro- or micro-segregation. When melted, metals can dissolve gases in some extent, independently on the gases present during the solidification process (oxygen, nitrogen, argon, etc.).

, and the presence of gas during solidification has different effects: it can react with the metal, form gas bubbles or even thin cracks yielding to brittle metals. Degassing is a crucial step during casting and it can be done by direct removal or using vacuum in different furnace configurations.

To predict the phase change in an alloy, the phase diagram and the lever rule are used to state the phases present, and their relative amounts and composition at a given temperature. To do so, 
it is assumed that the alloy remains in equilibrium throughout all the solidification/melting

2 process, and that it is possible only if the change in temperature is slow enough to allow

3 diffusion and nucleation to occur. The production of metal alloys focuses on obtaining the

4 desired microstructures with specific properties, and for this purpose, the whole process is

5 designed: melting, cooling and further heat treatment.

6

7 4. Challenges of using metal and metal alloys as storage materials, and how to approach them.

a. As discussed previously, the use of pure metals in TES high temperature applications is a promising solution. Nevertheless, some pure metals have quite a high vapour pressure, e.g. $\mathrm{Mg}, \mathrm{Zn}, \mathrm{Hg}$, Na that make them non-suitable to be as PCM. Selection of metals and alloys with low vapour pressures becomes crucial. Steel, copper and copper alloys without $\mathrm{Mg}, \mathrm{Zn}$

c. Most of metal alloys suggested for TES storage up to now are compositions close to the or $\mathrm{Na}$ are examples of PCM taking into account vapour pressure [38].

b. In pure metals, undercooling will occur either with homogeneous or heterogeneous nucleation. While this phenomenon is not crucial in industrial casting, it definitely must be taken into account in a TES system. For both $\mathrm{Mg}$ an $\mathrm{Al}$, undercooling is estimated to be above $100 \mathrm{~K}$ for homogeneous nucleation [38]. This data should be collected while considering a certain metal or alloy a suitable PCM. eutectic point of these alloys. The design of a storage process with implications in the microstructure, by forming metastable phases, precipitates, etc. was remarked by Chen et al. [39]. To maintain the phase-change transformation closer to the thermodynamic equilibrium conditions, the melting/solidification process should be as slow as possible. This will also favor the absence of thermal stresses in the bulk material when the cooling or heating front propagates inwards from the surface by diffusion. This can be translated to a lower diffusivity for the material. In order to maintain the phase-change transformation closer to the thermodynamic equilibrium conditions, the melting/solidification process should be as slow as possible.

The time $t$ that heat takes to go through a thickness $x$ in a material with diffusivity $a$, is:

$$
t=\frac{x^{2}}{2 a}
$$


So, in order to increase time, the diffusivity should be as low as possible [40-41]. As diffusivity is the relation between conductivity $(\lambda)$ and volumetric heat capacity $(\rho \cdot C p)$, the equation is as follows:

4

$t=\frac{x^{2}}{2} \frac{\rho C_{p}}{\lambda}$

Therefore, to increase lag time, we have to find metals or alloys with a relation $\frac{\rho C_{p}}{\lambda}$ as large as possible, or the inverse minimum. On the other hand, the metal or metal alloy, need to store a large amount of heat for a certain temperature ranges. Stored heat per unit volume can be calculated by (Eq. 3):

$Q_{\text {stored }}=\rho C_{p} \Delta T$ its thermal conductivity, transferred heat per unit volume become Eq. 4:

$$
Q_{\text {transferred }}=\lambda \frac{\Delta T}{x^{2}}
$$

Thus, $\rho \cdot C p$ should also be as large as possible. Following the material selection methodology described by Fernández et al. [40], if all these requirements are considered minimum, those metals or alloys with the lower diffusivity can be found but, at the same time, the highest thermal conductivity and volumetric heat capacity (see Figure 3). 


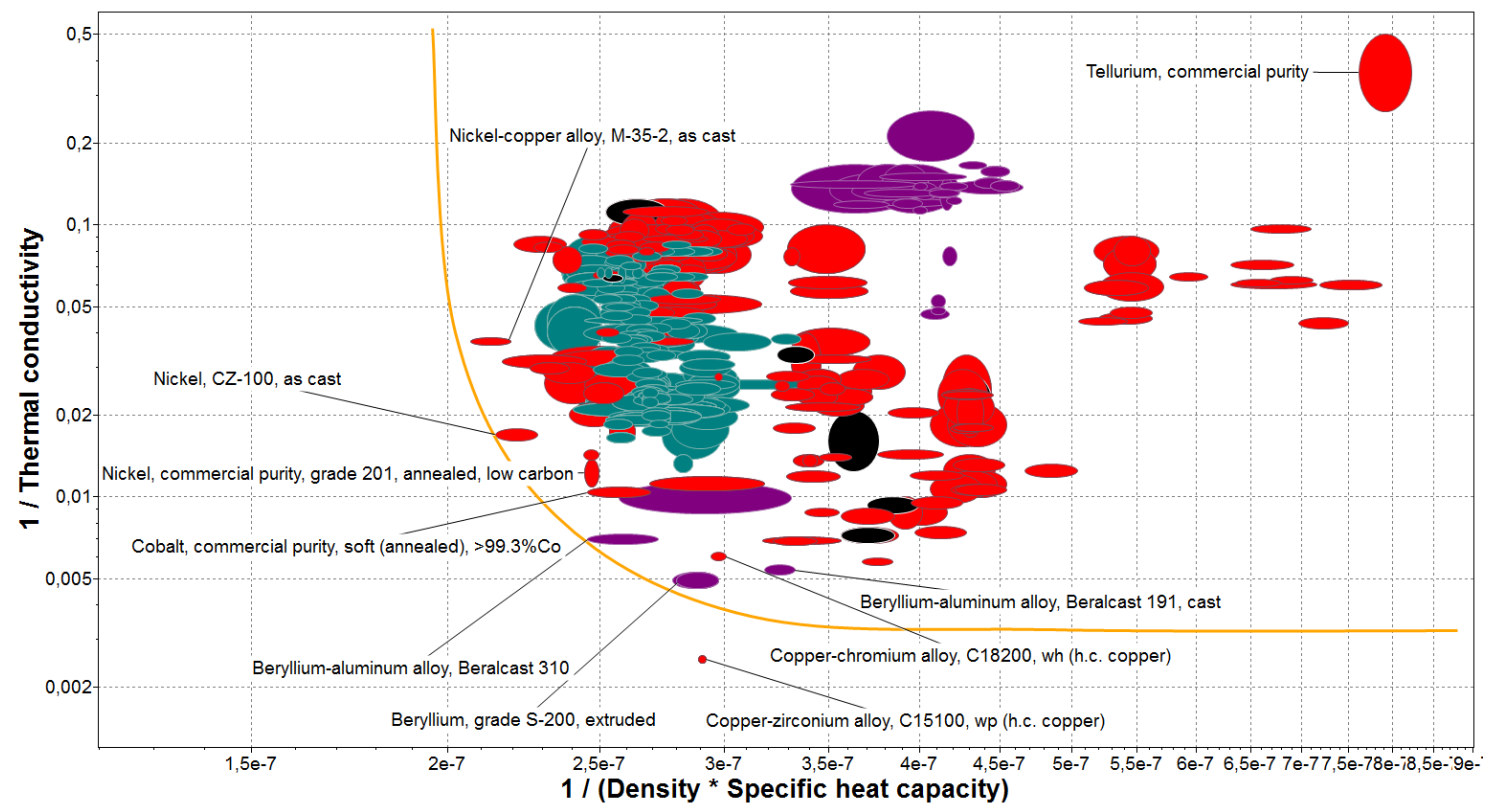

Figure 3. Thermal conductivity vs. $\rho \cdot C p$

Those materials that are closer to the Pareto front (curved line) present lower diffusivities, while the other properties are greater [40-41].

d. The heat transfer coefficient is very high in metal alloys. Hence, to use or choose a proper heat transfer fluid that allows working with these high heat transfer coefficients is a challenge in this field. Another important issue is the difference in expansion coefficients between the PCM and the container material. This should be reduced as much as possible in order to diminish thermal stresses [41].

e. In practice, most metal alloys require a heat treatment after the solidification to reach the desired microstructure that provides the required mechanical and chemical properties of these alloys in use. If this mechanical performance is not required, then this heat treatment can be excluded, but then the different heating and cooling cycles in their use as PCM may produce segregation or formation of insoluble precipitates. The effect of the number of heating/cooling cycles on the microstructure becomes an important parameter to be studied.

f. The formation of precipitates or oxides due to the change in cycling rates (which may be a requirement of the storage system) may change the alloy characteristics, and therefore melting and solidification temperatures as well as the enthalpy. Therefore, precipitates must be included in the boundary conditions in order to define the working condition limits.

g. Oxidation of alloys can be avoided with inert atmospheres, but each gas has a different influence that needs to be considered in the final solid phase formation. The effect of gases 
on molten metals has already been studied in the past, but the influence of retained gases in the solid metal or alloy during cycling needs a further research.

h. Encapsulation or containment represents a significant challenge, which is difficult to achieve cost effectively. A metal PCM can either be contained by a ceramic or a metal. With a ceramic, the differences in thermal expansion can expose the ceramic to significant strain, ultimately causing fracture. A metal containment/encapsulation can resolve this issue; however, there is a significant risk of corrosion through diffusion. Through this process intermetallic may form. Various oxide coatings could potentially overcome this issue.

i. Possible undesired reactions with the container, coil, pipes and liquid metal can take place ${ }^{40}$. Considerations within the system design step shall include the inquiry of the Ellingham diagrams. For instance, the use of refractory materials, which is common in the various types of industrial furnaces, shows an example of undesirable reactions between a magnesia brick and liquid aluminium following the reaction:

$$
2 \mathrm{MgO}(\mathrm{s})+4 / 3 \mathrm{Al}(\mathrm{l})=2 \mathrm{Mg}(\mathrm{g})+2 / 3 \mathrm{Al}_{2} \mathrm{O}_{3}(\mathrm{~s})
$$

On the other hand, experience from the metallurgical industry may help in the materials selection of the system, e.g. tool steel is used for die casting of $\mathrm{Al}$ and $\mathrm{Al}$ alloys. Compatibility of PCM and container materials should be tested.

j. Last but not least, the solidification during the phase change will be one of the most important processes to store thermal energy with metal and/or metal alloys. In practice, the speed of crystallization of a substance under solidification is defined by crystal structure, presence of crystallization centers, external conditions of heat exchange, etc as state by Kenisarin [17]. Moreover, high changes of volume during the melting and this fact can promote formation of voids during its solidification.

\section{Conclusions and recommendations}

Although some pure metals and metal alloys present interesting thermal properties to be used as PCMs in thermal storage systems, there is still a lack of consciousness about the implications of the metallurgical aspects related to melting and solidification of these materials under thermal cycling at high temperatures. 
The main issues to be considered have been summarized in this paper: vapour pressure, undercooling, corrosion, segregation, changes in composition and microstructure, changes in thermal properties, and undesired reactions. All of them seem to be sufficiently important by themselves, but significantly more research is needed before implementing these materials as PCMs in TES at industrial scale.

\section{Acknowledgments}

The research leading to these results has received funding from the European Commission Seventh Framework Programme (FP/2007-2013) under grant agreement $n^{\circ}$ PIRSES-GA-2013610692 (INNOSTORAGE) and from the European Union's Horizon 2020 research and innovation program under grant agreement No 657466 (INPATH-TES). The authors would like to thank the Catalan Government for the quality accreditation given to their research groups GREA (2014 SGR 123) and DIOPMA (2014 SGR 1543), and also the Spanish Government for the projects ENE2015-64117-C5-1-R and ENE2015-64117-C5-2-R (MINECO/FEDER, UE). Dr. Camila Barreneche would like to thank Ministerio de Economia y Competitividad de España for Grant Juan de la Cierva, FJCI-2014-22886. This paper was produced with support from the "Premier's Research and Industry Fund - International Research Grant Program", funded by the government of South Australia.

\section{References}

1. Lucon, O., Ürge-Vorsatz, D., Zain Ahmed, A., Akbari, H., Bertoldi, P., Cabeza, L.F., Eyre, N., Gadgil, L.D.D., Harvey, A., Jiang, Y., Liphoto, E., Mirasgedis, S., Murakami, S., Parikh, J., Pyke, C., Vilariño, M.V. Buildings. In: Climate Change 2014: Mitigation of climate change. Contribution of working group III to the fifth assessment report of the intergovernmental panel on climate change [Edenhofer, O., Pichs-Madruga, R., Sokona, Y., Farahani, E., Kadner, S., Seyboth, K., Adler, A., Baum, I., Brunner, S., Eickemeier, P., Kriemann, B., Savolainen, J., Schlömer, S., von Stechow, C., Zwickel, T., Minx, J.C. (eds.)]. Cambridge University Press, Cambridge, United Kingdom and New York, NY, USA. 2014

2. Ürge-Vorsatz, D., Cabeza, L.F., Serrano, S., Barreneche, C., Petrichenko, K. Heating and cooling energy trends and drivers in buildings. Renewable \& Sustainable Energy Reviews 41, 85-98. 2015.

3. Cabeza, L.F., Martorell, I., Miró, L., Fernández, A.I., Barreneche, C. Introduction to thermal energy storage (TES) systems. Advances in Thermal Energy Storage Systems: Methods and Applications 1-28. 2014. 
4. Gil, A., Medrano, M., Martorell, I., Lázaro, A., Dolado, P., Zalba, B., Cabeza, L.F. State of the art on high temperature thermal energy storage for power generation. Part 1Concepts, materials and modellization. Renewable \& Sustainable Energy Reviews 141, 31-55, 2010.

5. Cabeza, L.F., Galindo, E., Prieto, C., Barreneche, C., Inés Fernández, A. Key performance indicators in thermal energy storage: Survey and assessment. Renewable Energy 83, 820-827, 2015.

6. Cabeza, L.F., Castell, A., Barreneche, C., De Gracia, A., Fernández, A.I. Materials used as PCM in thermal energy storage in buildings: A review. Renewable and Sustainable Energy Reviews 15 (3), 1675-1695, 2011.

7. Liu M, Saman W and Bruno, F. Review on storage materials and thermal performance enhancement techniques for high temperature phase change thermal storage systems. Renewable and Sustainable Energy Reviews 16, 2118-2132, 2012.

8. Francis Agyenim, Neil Hewitt, Philip Eames, Mervyn Smyth. A review of materials, heat transfer and phase change problem formulation for latent heat thermal energy storage systems (LHTESS). Renewable and Sustainable Energy Reviews 14, 615-628, 2010.

9. Barreneche, C. et.al Thermal Energy Storage (TES): Requirements and constrains for a material-based design. Materials Science and Technology Conference and Exhibition 2014, MS\&T2014, 3,1651-1658, 2014.

10. Gasanaliev, A.M, Gamataeva, B.Y. Heat-accumulating properties of melts. Russian Chemical Reviews 69(2),179-186, 2000.

11. Magomedov A.M. Netraditsionnye Istochniki Energii (Non-Traditional Sources of Energy. Makhachkala: Yupiter, 1996

12. Martynova, N.M., Rodionova, E.K., Tishura, T.A., Cherneeva, L.I. Akkumulirovanie Energii i Puti, Povysheniya Effektivnosti Raboty Elektrostantsii i Ekonomii Energii. Akkumuliruyushchie Energoustanovki, Teplovye Protsessy i Teploakkumuliruyushchie Materialy (Energy Storage and Ways of Increasing the Efficiency of Operation of Power Plants and Economy of Energy). Stored Power Plants, Thermal Processes and HeatStorage Materials. Moscow: Khimiya, 2, 167, 1986.

13. Danilin,V.N., Shurai, P.E., Sryvalin, I.T., Krasnodar, Tr. Politekh. In-ta 65, 1969.

14. Sharma, A., Tyagi, V.V., Chen, C.R., Buddhi, D. Review on thermal energy storage with phase change materials and applications. Renewable and Sustainable Energy Reviews 13, 318-345, 2009.

15. Rathod, M.K., Barnerjee, J. Thermal stability of phase change materials used in latent heat energy storage systems: A review. Renewable \& Sustainable Energy Reviews 18, 246-258, 2013. 
16. Birchenall, C.E., Telkes, M. Thermal storage in metal. In: Sharing the sun: solar technology in the seventies-joint conf. American section of ISES and solar energy society of Canada 8, 38-54, 1976.

17. Kenisarin, M.M. High-temperature phase change materials for thermal energy storage. Renewable and Sustainable Energy Reviews 14, 955-970, 2010.

18. Birchenall, C.E., Riechman, A.F. Heat storage in eutectic alloys. Metallurgical Transactions A 11A (8), 1415-1420, 1980.

19. Farkas D., Birchenall C.E. New eutectic alloys and their heats of transformation. Metallurgical Transaction A16A,324-328, 1985.

20. Wang, X., Liu, J., Zhang, Y., Di, H., and Jiang, Y. Experimental Research on a Kind of Novel High Temperature Phase Change Storage Heater. Energy Conversion and Management 47, 2211-2222, 2006.

21. Sun JQ, Zhang RY, Liu ZP, Lu GH. Thermal reliability test of Al-34\% Mg-6\% Zn alloy as latent heat storage material and corrosion of metal with respect to thermal cycling. Energy Convers Manage 48,617-624, 2007.

22. Gunasekara S.N., Martin V., Chiu J.N. Phase equilibrium in the design of phase change materials for thermal energy storage: State-of-the-art. Renewable and Sustainable Energy Reviews 73, 558-581, 2017.

23. Cárdenas, B., León, N. High temperature latent heat thermal energy storage: Phase change materials, design considerations and performance enhancement techniques. Renewable \& Sustainable Energy Reviews 27, 724-737, 2013.

24. Trunin, A.S. Designing and investigations of salt systems for solar energy utilization. Utilization of sun and other radiation sources in materials research. Kiev: Naukova Dumka 228-238, 1983.

25. Blanco-Rodríguez, P., Rodríguez-Aseguinolaza, J., Risueño, E., Tello, M.. Thermophysical characterization of Mg51\%Zn eutectic metal alloy: A phase change material for thermal energy storage in direct steam generation applications. Energy 72, 414-420, 2014.

26. Khare, S., Dell'Amico, M., Knight, C., McGarry, S. Selection of materials for high temperature latent heat energy storage. Solar Energy Materials \& Solar Cells 107, 20-27, 2012.

27. Petri, R.J., Ong, E.T. High temperature composite thermal energy storage (TES) Systems for industrial applications. In: Proceedings of the 21st intersociety energy conversion engineering conference 2, 873-880, 1986.

28. Kotzé, J.P., von Backström, T.W., Erens, P.J. High temperature thermal energy storage utilizing metallic phase change materials and metallic heat transfer fluids. Journal of Solar Energy Engineering ASME 135, 035001, 2013. 
29. Li, F., Hu, Y., and Zhang, R., 2011, "The Influence of Heating-Cooling Cycles on the Thermal Storage Performances of Al-17 Wt.\% Si Alloy," Adv. Mater. Res., 239-242, pp. $2248-2251$.

30. Akiyama, T., Ashizawa, Y., Yagi, J. Storage and release of heat in a single spherical capsule containing phase-change material with a high melting point. Heat Transfer Japanese Research 21,199-217, 1992.

31. He, Qiao and Zhang, Wennan. A study on latent heat storage exchangers with the hightemperature phase-change material. International Journal of Energy Research 25, 331$341,2001$.

32. Kotzé, J.P., von Backström, T.W., Erens, P.J. Simulation and testing of a latent heat thermal energy storage unit with metallic phase change material. Energy Procedia 49, 860-869, 2014.

33. Zhang, G., Li, J., Chen, Y., Xiang, H., Ma, B., Xu, Z., Ma, X. Encapsulation of copperbased phase change materials for high Temperature thermal energy storage. Solar Energy Materials \& Solar Cells 128, 131-137, 2014.

34. Ma, B., Li, J., Xu, Z., Peng, Z. Fe-shell/Cu-core encapsulated metallic phase change materials prepared by aerodynamic levitation method. Applied Energy 132, 568-574, 2014.

35. Andraka, C.E., Kruizenga, A.M., Hernandez-Sanchez, B.A., Coker, E.N. Metallic Phase Change Material Thermal Storage for Dish Stirling. Energy Procedia 69, 726-736, 2016.

36. He, Q., Zhang, W. A Study on Latent Heat Storage Exchangers With the HighTemperature Phase-Change Material. International Journal of Energy Research 25, 331$341,2001$.

37. Risueño, E., Doppiu, S., Rodríguez-Aseguinolaza, J., Blanco, P., Gil, A., Tello, M., Faik, A., D'Aguanno, B. Experimental investigation of $\mathrm{Mg}-\mathrm{Zn}-\mathrm{Al}$ metal alloys for latent heat storage application. Journal of Alloys and Compounds 685, 724-732,

38. Cottrell, A. An introduction to metallurgy. Edward Arnold Publisher (second edition), ISBN: 0713125101, London, UK, 1975.

39. Chen, G. Ren, Z., Esfarjani, K. Metallic Composites Phase-Change Materials for HighTemperature Thermal Energy Storage. SunShot conference (Department of Energy) 2013.

40. Fernandez, A.I., Martínez, M., Segarra, M., Martorell, I., Cabeza, L.F. Selection of materials with potential in sensible thermal energy storage. Solar Energy Materials \& Solar Cells 94 (10), 1723-1729, 2010.

41. Ashby, M., Shercliff, H., Cebon, D. Materials: engineering, science, processing and design. Elsevier Ltd., UK, 2007. 
A. Risueño, E., Doppiu, S., Rodríguez-Aseguinolaza, J., Blanco, P., Gil, A., Tello, M., Faik, A., D'Aguanno, B. Experimental investigation of Mg-Zn-Al metal alloys for latent heat storage application. Journal of Alloys and Compounds 685, 724-732, 2016. 